\title{
Evaluation of functional outcome of tibial plateau fractures managed by different surgical modalities
}

\author{
Ravi Kant Jain ${ }^{1}$, Rajeev Shukla ${ }^{1}$, Mudit Baxi ${ }^{1 *}$, Utkarsh Agrawal ${ }^{1}$, Sankalp Yadav ${ }^{2}$ \\ ${ }^{1}$ Department of Orthopaedics, Sri Aurobindo Medical College and Post Graduate Institute, Indore, Madhya Pradesh, \\ India \\ ${ }^{2}$ Department of Medicine \& TB, Chest Clinic Moti Nagar, North Delhi Municipal Corporation, New Delhi, India
}

Received: 03 March 2016

Accepted: 12 March 2016

*Correspondence:

Dr. Mudit Baxi,

E-mail: muditbaxi@yahoo.com

Copyright: $(\odot$ the author(s), publisher and licensee Medip Academy. This is an open-access article distributed under the terms of the Creative Commons Attribution Non-Commercial License, which permits unrestricted non-commercial use, distribution, and reproduction in any medium, provided the original work is properly cited.

\begin{abstract}
Background: Tibial plateau makes up one of the most important weight bearing surface. Its fractures are commonly faced entity encompassing a wide spectrum of injuries of variable fracture morphology. Due to in-crease in incidence of high velocity trauma and higher functional demands of patients, surgery is warranted in most of the cases. Although, there is advancement in fracture fixation methods, apt treatment of tibial plateau fractures still remains controversial.

Methods: In our series, we analyzed the functional outcomes of 58 of surgically treated tibial plateau fractures. Fractures were classified with Schatzker's classification. Various fixation modalities of fixation were employed. Functional outcome was evaluated with modified Rasmussen's criteria.

Results: Most of the patient's belonged to younger age groups (58.62\%) and males $(79.31 \%)$ were predominately involved. Road traffic accidents were the most common etiological factor (70.69\%). Schatzker types I (29.31\%) and II $(27.59 \%)$ were the most common observed fracture type. The majority of the patients had a complication free recovery $(81.03 \%)$. Infection was reported in only one case $(1.72 \%)$. Similarly, malunion was noticed in only in one case $(1.72 \%)$. None of the patients had complications like nonunion or neurovascular damage. The functional outcome assessment according to Modified Rasmussen's criteria at the end of 12 months showed the excellent functional outcome in $41(70.68 \%)$, good in eight $(13.79 \%)$, fair in five (10.34\%) and poor in four (6.9\%) patients.

Conclusions: Surgical treatment of tibial plateau fractures is challenging, yet it helps in achieving excellent anatomical restoration and rigid fracture fixation enabling in the restoration of articular congruity and facilitation of early knee motion thus achieving optimal knee function.
\end{abstract}

Keywords: Fracture, Internal fixation, Operative management of tibial plateau fractures, Tibial plateau

\section{INTRODUCTION}

The tibial plateau is the region of proximal tibia, which comprises of the superior articular surface. It constitutes a major weight bearing area in the body. Its fractures classically were described as bumper or fender's fractures. They gravely affect the biomechanics, stability and range of motion of the knee joint. ${ }^{1,2}$ These injuries present with a wide array of fractures, varying from minor hairline cracks with excellent functional outcomes even after conservative treatment to challenging fracture configurations requiring highly experienced surgical hands.

Tibial plateau fractures represent approximately one percent $(1 \%)$ of fractures in adults. ${ }^{3}$ These occur in both the young and the elderly age groups. In younger patients, men are frequently involved owing to their 
predisposition for high velocity trauma. As the age advances, women are the frequent patients as more and more fractures occur in the porous bones. Associated injuries in the vicinity of the knee joint are common. Surrounding structures such as ligaments around the knee are commonly involved in varying severity.

These fractures are commonly classified on the basis of their radiological appearance. Commonly used systems are Schatzker's and AO/OTA classification systems. The Schatzker classification is based on the fracture morphology and guides the surgeon to formulate line of treatment. The AO/OTA classification is also well accepted and defines the fracture morphology precisely.,

Treatment concepts based on restoring or preserving limb alignment lead to a satisfactory outcome for most patients. Poor alignment often results in a poor outcome. New methods have changed the surgical management of both low-energy lateral plateau fractures and high-energy medial and bi-condylar fractures, but more data is necessary to determine if these new methods are improving patient outcomes.

The treatment of tibial plateau fractures is continuously evolving. Various techniques have emerged over the last few decades. Until the seventies, these fractures were essentially treated conservatively with a variety of modalities such as traction, cast bracing and spica casting. $^{6-10}$

In the eighties, as the science of internal fixation progressed rapidly, more and more tibial plateau fractures started to get operated. ${ }^{4,11,12}$ Surgically treated fractures yielded favorable results due to the achievement of better articular congruity, higher stability and early mobilization. As the propen-sity of high velocity trauma increased, the incidence of complex fractures also increased and thus more and more fractures were subjected to surgical reductions.

As more tibial plateau fractures are surgically treated, surgical complications, have become relatively common. Surgical methods for reducing and fixing tibial plateau fractures have evolved over the last three or four decades in order to identify techniques that minimize complications and other techniques that optimize the treatment of complications when they occur.

\section{METHODS}

The study was conducted in settings of Department of Orthopaedics and Traumatology, Sri Auro-bindo Medical College and Post Graduate Institute, Indore, Madhya Pradesh. The study period was from August 2013 to July 2015. In this prospective short-term trial, 58 consecutive patients treated surgically for tibial plateau fractures were selected on the basis of history, clinical examination and radiography. The Schatzker classification ${ }^{4}$ was used to classify these fractures. The patients were followed up for a period of one year. (at intervals of two weeks, six weeks, three months, six months and one year). At the end of six months and one year, functional (based on Modified Ras-mussen Criteria ${ }^{13}$ ) outcome based evaluation was done.

\section{Inclusion criteria}

- Age group 18 years and above

- Patient with closed tibial plateau fracture

\section{Exclusion criteria}

- Open fractures of the tibial plateau

- Any other associated injury or fracture

- Patients with head injury

Surgical approach adopted was governed by the geometry of the fracture: (i) Anterolateral approach: This approach was used for osteosynthesis of fractures of the lateral tibial plateau. (ii) Minimal invasive anterolateral approach: This approach is useful in fixation of fractures, which did not involve the joint surface, or where reduction and fixation of the intra-articular element of the fracture could be done without direct visualization of the joint surface. (iii) Posteromedial approach: Used for osteosynthesis of fractures of the medial tibial plateau. Selection of implant was carried out intra-operatively after the achievement of reduction after direct visualization and IITV guidance.

As a routine, patients were mobilized 48 hours after drain removal, for an initial three to five days the range of motion allowed was $0-20^{\circ}$, from the sixth day the range of motion was gradually al-lowed to be increased to $90^{\circ}$ or more.

After suture removal, full range of movement was permitted. Range of motion exercises was encouraged under supervision. All the patients were taught and advised to do static quadriceps exercises and dynamic exercises with a quadriceps board as much as possible. Partial weight bearing was allowed after six to eight weeks and full weight bearing allowed after 12-16 weeks. Patients were discharged routinely on the fifth postoperative day (POD) and followed up with a regular schedule, starting from postoperative day $13^{\text {th }}$ for suture removal and followed up at six weeks, three months, six months and at the end of one year. They were clinically and radiologically assessed. All the details were noted in accordance with modified Rasmussen's score. ${ }^{13}$

\section{RESULTS}

Observation and analysis of results were done in context to the age, sex, occupation, laterality of fracture, type of fracture, method of treatment, duration of immobilization, complications and the remarks of different age groups in details as follows. 


\section{Age wise distribution}

The incidence of tibial plateau fractures is high among young population due to increase in cases of road traffic accidents, the major etiological factor in the occurrence of such fractures.

In this study, the majority of the population lies between age group of 30-39 years were $20(34.48 \%)$ and between 20-29 years were $13(22.41 \%)$ (Table 1$)$.

Table 1: Distribution of patients, according to the age.

\begin{tabular}{|ll|l|}
\hline Age group & Number & Percentage \\
\hline$<20$ years & 1 & 1.72 \\
\hline $20-29$ years & 13 & 22.41 \\
\hline $30-39$ years & 20 & 34.48 \\
\hline $40-49$ years & 11 & 18.97 \\
\hline $50-59$ years & 6 & 10.34 \\
\hline$>59$ years & 7 & 12.07 \\
\hline Total & 58 & 100.00 \\
\hline
\end{tabular}

\section{Gender wise distribution}

In this series, the wide gender disparity has been observed. Number of male patients being 46 (79.31\%) and female being $12(20.69 \%)$.

\section{Distribution according to level of activities}

We have observed that the majority of our study population was involved in high level of occupational activity-28 (48.28\%) i.e. labourer, farmer, manual worker.

\section{Distribution according to mode of injury}

Road traffic accidents were found to be the most common mode of injury i.e. $41(70.69 \%)$ as compared to other mode of injuries i.e. $17(29.31 \%)$. The other modes of injury being fall from height, assault, athletic injuries, etc (Table 2).

Table 2: Distribution of patients, according to mode of injury.

\begin{tabular}{|l|l|l|}
\hline Mode of Injury & Number & Percentage \\
\hline RTA & 41 & 70.69 \\
\hline Others & 17 & 29.31 \\
\hline Total & 58 & 100.00 \\
\hline
\end{tabular}

\section{Distribution according to laterality}

Right side has shown to be more predominantly involved in this series-32 (55.17\%) as compared to the left-26 $(44.83 \%)$.

\section{Distribution according to Schatzker ${ }^{4}$ classification type}

In our series, we observed that the most commonly involved part of the tibial plateau is the lateral condyle. Its pure split accounts for $17(29.31 \%)$ and its split associated with depression accounts for 16 (27.59\%) of cases. While isolated fractures of medial condyle are associated with least of cases-4 (6.90\%) (Table 3).

Table 3: Distribution of patients, according to classification.

\begin{tabular}{|lll|}
\hline Classification & Number & Percentage \\
\hline I & 17 & 29.31 \\
\hline II & 16 & 27.59 \\
\hline III & 8 & 13.79 \\
\hline IV & 4 & 6.90 \\
\hline V & 5 & 8.62 \\
\hline VI & 8 & 13.79 \\
\hline Total & 58 & 100.00 \\
\hline
\end{tabular}

\section{Distribution of patients in accordance with involvement} in complications

We observed that $47(81.03 \%)$ of the cases went through an uneventful course of recovery. While implant prominence in three $(5.17 \%)$ and wound dehiscence in three $(5.17 \%)$ were the most common complications (Table 4).

Table 4: Distribution of patients, according to complications.

\begin{tabular}{|lll|}
\hline Complications & Number & Percentage \\
\hline None & 47 & 81.03 \\
\hline Implant prominence & 3 & 5.17 \\
\hline Infection & 1 & 1.72 \\
\hline Malunion & 1 & 1.72 \\
\hline Stiffness & 2 & 3.45 \\
\hline Stiffness with infection & 1 & 1.72 \\
\hline Wound dehiscence & 3 & 5.17 \\
\hline Total & 58 & 100.00 \\
\hline
\end{tabular}

\section{Association of functional outcome with level of activity}

It was observed that the high activity group had the better functional outcome as compared with moderate and sedentary groups. It yielded 22 excellent results out of 28 patients (Table 5).

\section{Functional outcome based on classification type}

Type I

In type I fractures two modalities were used. It was found that the plating has higher mean MRS at the end of 12 months with 28.33 than CC Screws with 26. MRS at 12 
months is seen to be higher than MRS at six months in both the modalities (Table 6A), (Figure 1).

Table 5: Association of Rasmussen ${ }^{13}$ grading in relation to level of activity at 12 months.

\begin{tabular}{|llllll|}
\hline Level of & \multicolumn{5}{l}{ Mean Rasmussen score at 12 months } \\
activity & Poor & Fair & Good & Excellent & Total \\
\hline Sedentary & 2 & 1 & 4 & 8 & 15 \\
\hline Moderate & 1 & 2 & 1 & 11 & 15 \\
\hline High & 1 & 2 & 3 & 22 & 28 \\
\hline Total & 4 & 5 & 8 & 41 & 58 \\
\hline
\end{tabular}

Table 6A: Functional outcome of type I fractures.

\begin{tabular}{|c|c|c|c|c|c|}
\hline $\begin{array}{l}\text { Treatment } \\
\text { modality }\end{array}$ & $\begin{array}{l}\text { No of } \\
\text { cases }\end{array}$ & $\begin{array}{l}\text { MRS } \\
(6 m)\end{array}$ & $\begin{array}{l}\text { MRS } \\
(12 M)\end{array}$ & $\begin{array}{l}\text { 't' } \\
\text { value }\end{array}$ & $\begin{array}{l}\mathbf{P} \\
\text { value }\end{array}$ \\
\hline CC Screw & 14 & $\begin{array}{l}24.29 \\
\pm 3.54\end{array}$ & $\begin{array}{l}25.86 \\
\pm 3.86\end{array}$ & $\begin{array}{l}-3.38, \\
d f=13\end{array}$ & $0.005 *$ \\
\hline Plating & 3 & $\begin{array}{l}26.67 \\
\pm 0.58\end{array}$ & $\begin{array}{l}28.00 \\
\pm 1.00\end{array}$ & $\begin{array}{l}-1.51 \\
\mathrm{df}=2\end{array}$ & 0.270 \\
\hline
\end{tabular}

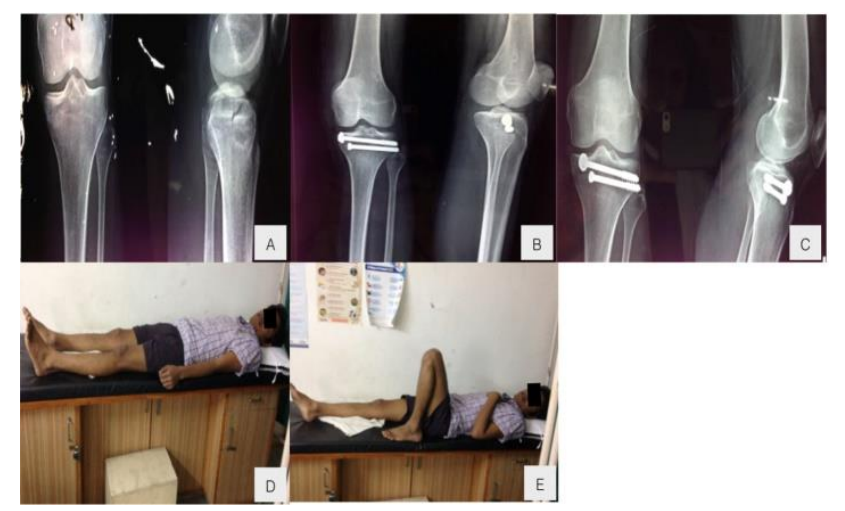

Figure 1: A case of Schatzker type I fracture treated with C.C. insertion.

A: Preoperative radiograph; B: Postoperative radiograph; C: 12 month follow-up radiograph; D, E: Clinical images at 12 months follow-up.

Type II

In type II fractures two modalities were used. It was found that plating along with C.C. Screws has higher mean MRS at the end of 12 months $(28)^{12}$ than plating alone (26.37). MRS at 12 months is seen to be higher than MRS at six months in both the modalities (Table 6B), (Figure 2).

Table 6B: Functional outcome of type II fractures.

\begin{tabular}{|llllll|}
\hline $\begin{array}{l}\text { Treatment } \\
\text { modality }\end{array}$ & $\begin{array}{l}\text { No of } \\
\text { cases }\end{array}$ & $\begin{array}{l}\text { MRS } \\
(\mathbf{6} \mathbf{m})\end{array}$ & $\begin{array}{l}\text { MRS } \\
(\mathbf{1 2 M})\end{array}$ & $\begin{array}{l}\text { 't' } \\
\text { value }\end{array}$ & $\begin{array}{l}\text { P } \\
\text { value }\end{array}$ \\
\hline Plating & 8 & $\begin{array}{l}23.50 \\
\pm 5.32\end{array}$ & $\begin{array}{l}26.38 \\
\pm 2.97\end{array}$ & $\begin{array}{l}-2.10, \\
\mathrm{df}=7\end{array}$ & 0.074 \\
\hline $\begin{array}{l}\text { Plating }+ \\
\text { CC Screw }\end{array}$ & 8 & $\begin{array}{l}26.63 \\
\pm 1.69\end{array}$ & $\begin{array}{l}28.00 \\
\pm 1.93\end{array}$ & $\begin{array}{l}-2.99, \\
\mathrm{df}=7\end{array}$ & $0.020^{*}$ \\
\hline
\end{tabular}

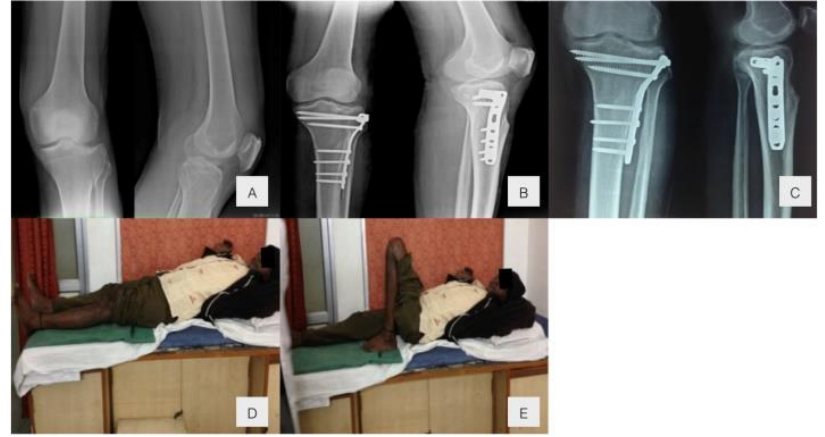

Figure 2: A case of Schatzker type II fracture treated with plate fixation.

A: Preoperative radiograph; B: Postoperative radiograph; C: 12 month follow-up radiograph; D,E: Clinical images at 12 month follow-up.

Type III

In type III fractures two modalities were used. It was found that the plating has higher mean MRS at the end of 12 months (29.25) than plating with CC screws (28.5). MRS at 12 months is seen to be higher than MRS at six months in both the modalities (Table 6C).

Table 6C: Functional outcome of type III fractures.

\begin{tabular}{|llllll|}
$\begin{array}{l}\text { Treatment } \\
\text { Modality }\end{array}$ & $\begin{array}{l}\text { No of } \\
\text { Cases }\end{array}$ & $\begin{array}{l}\text { MRS } \\
(\mathbf{6 m})\end{array}$ & $\begin{array}{l}\text { MRS } \\
(\mathbf{1 2} \mathbf{m})\end{array}$ & $\begin{array}{l}\text { ' } \mathrm{t} \text { ' } \\
\text { value }\end{array}$ & $\begin{array}{l}\mathbf{P} \\
\text { value }\end{array}$ \\
\hline Plating & 4 & $\begin{array}{l}26.25 \\
\pm 0.50\end{array}$ & $\begin{array}{l}29.00 \\
\pm 1.41\end{array}$ & $\begin{array}{l}-4.37, \\
\mathrm{df}=3\end{array}$ & $0.022^{*}$ \\
\hline Plating + & 4 & 25.50 & 28.75 & -3.81, & $0.032 *$ \\
CC Screw & & \pm 1.92 & \pm 0.50 & $\mathrm{df}=3$ & \\
\hline
\end{tabular}

Type IV

In type IV fractures two modalities were used. It was found that C.C. Screws have higher mean MRS at the end of 12 months-28.5 than plating-20. MRS at 12 months is seen to be higher than MRS at six months in both the modalities (Table 6D).

Table 6D: Functional outcome of type IV fractures.

\begin{tabular}{|llllll|}
\hline $\begin{array}{l}\text { Treatment } \\
\text { Modality }\end{array}$ & $\begin{array}{l}\text { No of } \\
\text { Cases }\end{array}$ & $\begin{array}{l}\text { MRS } \\
(\mathbf{6 m})\end{array}$ & $\begin{array}{l}\text { MRS } \\
(\mathbf{1 2 M})\end{array}$ & $\begin{array}{l}\text { 't' } \\
\text { value }\end{array}$ & $\begin{array}{l}\text { P } \\
\text { value }\end{array}$ \\
\hline CC Screw & 2 & 25.50 & 28.00 & -1.67, & 0.344 \\
& & \pm 0.71 & \pm 1.41 & $\mathrm{df}=1$ & \\
\hline Plating & 2 & 19.00 & 20.50 & -3.00, & 0.205 \\
& & \pm 9.89 & \pm 9.19 & $\mathrm{df}=1$ & \\
\hline
\end{tabular}

Type V

In type $\mathrm{V}$ fractures two modalities were used. It was found that dual plating has higher mean MRS at the end of 12 months (29.5) than plating with CC screws (21.33). MRS at 12 months is seen to be higher than MRS at 6 months in both the modalities (Table 6E). 
Table 6E: Functional outcome of type $V$ fractures.

\begin{tabular}{|llllll|} 
Treatment & $\begin{array}{l}\text { No of } \\
\text { modality }\end{array}$ & $\begin{array}{l}\text { MRS } \\
(\mathbf{6 m})\end{array}$ & $\begin{array}{l}\text { MRS } \\
(\mathbf{1 2 M})\end{array}$ & $\begin{array}{l}\text { 't' } \\
\text { value }\end{array}$ & $\begin{array}{l}\mathbf{P} \\
\text { value }\end{array}$ \\
\hline Dual & 2 & 27.00 & 29.50 & -5.00, & 0.126 \\
Plating & & \pm 1.41 & \pm 0.71 & $\mathrm{df}=1$ & \\
\hline Plating + & 3 & 19.67 & 21.33 & -5.00, & $0.038^{*}$ \\
CC Screw & & \pm 7.09 & \pm 7.02 & $\mathrm{df}=2$ & \\
\hline
\end{tabular}

Type VI

In type VI fractures three modalities were used. It was found that plating with C.C. Screw has higher mean MRS at the end of 12 months (28.6) than dual plating-24 followed by plating (15). MRS at 12 months is seen to be higher than MRS at 6 months in dual plating and plating with C.C. screw group (Table 6F).

Table 6F: Functional outcome of type VI fractures.

\begin{tabular}{|llllll|}
$\begin{array}{l}\text { Treatment } \\
\text { modality }\end{array}$ & $\begin{array}{l}\text { No of } \\
\text { Cases }\end{array}$ & $\begin{array}{l}\text { MRS } \\
(\mathbf{6 m})\end{array}$ & $\begin{array}{l}\text { MRS } \\
(\mathbf{1 2 M})\end{array}$ & $\begin{array}{l}\text { ' } \mathbf{t} \text { value } \\
\text { value }\end{array}$ & $\begin{array}{l}\text { P } \\
\text { value }\end{array}$ \\
\hline $\begin{array}{l}\text { Dual } \\
\text { Plating }\end{array}$ & 2 & $\begin{array}{l}22.00 \\
\pm 5.66\end{array}$ & $\begin{array}{l}24.00 \\
\pm 5.66\end{array}$ & - & - \\
\hline Plating & 1 & $\begin{array}{l}15.00 \\
15.00\end{array}$ & - & - \\
& & \pm 0.00 & \pm 0.00 & & \\
\hline Plating + & 2 & 26.40 & 28.40 & -3.16, & $0.034^{*}$ \\
CC Screw & & \pm 1.82 & \pm 1.14 & $\mathrm{df}=1$ & \\
\hline
\end{tabular}

Table 7A: Distribution of patients, according to modified Rasmussen grading at six months.

\begin{tabular}{|lll|}
\hline Rasmussen grading & Number & Percentage \\
\hline Poor $(<20)$ & 6 & 10.34 \\
\hline Fair $(20-23)$ & 7 & 12.07 \\
\hline Good $(24-27)$ & 34 & 58.62 \\
\hline Excellent $(28-30)$ & 11 & 18.97 \\
\hline Total & 58 & 100.00 \\
\hline Mean \pm SD & $24.50 \pm 4.15$ \\
\hline
\end{tabular}

Table 7B: Distribution of patients, according to modified Rasmussen grading at 12 months.

\begin{tabular}{|lll|}
\hline Rasmussen grading & Number & Percentage \\
\hline Poor $(<20)$ & 4 & 6.90 \\
\hline Fair $(20-23)$ & 5 & 10.34 \\
\hline Good $(24-27)$ & 8 & 13.79 \\
\hline Excellent $(28-30)$ & 41 & 70.68 \\
\hline Total & 58 & 100.00 \\
\hline Mean \pm SD & $26.50 \pm 4.03$ \\
\hline
\end{tabular}

Distribution of patients, according to Modified Rasmussen Grading. ${ }^{13}$

At the end of six months it was observed that most of the patients fell under "good" MRS grade-11 (58.62\%) followed by "excellent"-11 (18.97\%), “fair"-seven (12.07\%) and "poor"-six (10.34\%) (Table 7A). Whereas, at the end of 12 months it was observed that most of the patients fell under "excellent" MRS grade-41 (70.68\%) followed by "good"- eight (13.79\%), "fair"-five (10.34\%) and "poor"-04 (6.90\%) (Table 7B).

\section{DISCUSSION}

Tibial plateau fractures, one of the common intra articular fractures, are major traumatic injury occurring as a result of RTA, fall from height, violence, etc. It is sometimes associated with other bony or soft tissue injuries. Any fracture around the joint (especially weight bearing knee joint in the lower limb) is of paramount importance as would result in significant morbidity and quality of life. Hence the treatment of upper tibial fractures with intra articular extension has become a challenge for the orthopaedic surgeons.

Our study included 58 patients with such fractures treated surgically at our institute. The analysis of the results was made in terms of-age of the patient, sex distribution, occupation, mode of violence, laterality of the fracture, analysis of the types, modalities of treatment, complications associated injuries and the functional outcome. We have endeavoured to present the various types of tibial plateau fractures in our central Indian setup.

The majority of fracture occurs between the age of 20 and 60 years with a maximum incidence of fractures occurring in the age group of 30-39 years (34.48\%). Our study also correlates well with other studies in the literature which also show increased incidence in 20-60 year group (Table 8).

Table 8: Mean age (in years) in various studies from the literature.

\begin{tabular}{|ll|}
\hline Study & Mean age (years) \\
\hline Honkonen $^{14}$ & 39.8 \\
\hline Stevens $^{15}$ & 40 \\
\hline Myatt $^{16}$ & 43.6 \\
\hline Our Study & 38.9 \\
\hline
\end{tabular}

In this study majority of the patients were males-46 out of $58(79.31 \%)$. This can be attributed to the Indian setup where males are more involved in outdoor activities and thus more liable for such injuries. Moore et $\mathrm{al}^{17}$ reported on a population of 752 patients with tibial plateau fractures found an average $62 \%$ of fractures occurring in men (Table 9).

Table 9: Showing gender distribution in various studies from the literature.

\begin{tabular}{|lll|}
\hline Study & Male & Female \\
\hline Moore $^{17}$ & $62 \%$ & $38 \%$ \\
\hline Unnikrishnan $^{18}$ & $76 \%$ & $24 \%$ \\
\hline Our Study & $79 \%$ & $21 \%$ \\
\hline
\end{tabular}


In our series, road traffic accidents were the most common mode of injury, accounting to $70.69 \%$ of cases. Rademakers et $\mathrm{al}^{19}$ (2007) conducted a study of 109 cases of tibial plateau fractures. They reported $55 \%$ cases as a result of road traffic accidents (Table 10).

Table 10: Showing percentage of RTA as mode of injury in various studies from the literature.

\begin{tabular}{|ll|}
\hline Study & \% of RTA as mode of Injury \\
\hline Rademakers $^{19}$ & $55 \%$ \\
\hline Manidakis $^{20}$ & $86 \%$ \\
\hline C.Dall'Oca & 21 \\
\hline Our Study & $64 \%$ \\
\hline
\end{tabular}

In our series Schatzker I and II were most commonly classified fractures types $(29.3 \%, 27.59 \%)$, while type IV fractures were amongst least commonly occurring injuries. Varying degree of incidences of various fracture types have been reported in the literature. However, it was found that incidences of low energy types (Schatzker I, II, III) are much higher than the rest (Table 11).

In this series, $81 \%$ of fractures were found to be free of any complications. While $19 \%$ had complications, which is similar to complication rate of Moore et $\mathrm{al}^{17}$ (19\% of all operated cases) (Table 12).

Table 11: Showing distribution of patients, according to Schatzker type.

\begin{tabular}{|ll|llll|}
\hline Type & Schatzker $^{4}$ & Honkonen $^{14}$ & Ebraheim $^{22}$ & Mytatt $^{16}$ & Our Study $^{\text {Ond }}$ \\
\hline I & $6 \%$ & $11.5 \%$ & $27 \%$ & $7.5 \%$ & $29.3 \%$ \\
\hline II & $25 \%$ & $30.5 \%$ & $30.76 \%$ & $30 \%$ & $27.59 \%$ \\
\hline III & $36 \%$ & $9.9 \%$ & $9.4 \%$ & $2.5 \%$ & $13.79 \%$ \\
\hline IV & $10 \%$ & $9.2 \%$ & $5.12 \%$ & $20 \%$ & $6.9 \%$ \\
\hline V & $3 \%$ & $21.3 \%$ & $18.8 \%$ & $27.5 \%$ & $8.62 \%$ \\
\hline VI & $20 \%$ & $17.5 \%$ & $12.8 \%$ & $12.5 \%$ & $13.79 \%$ \\
\hline
\end{tabular}

Implant prominence and wound dehiscence were the most common complications (3\% respectively). While, other being: stiffness (2\%), malunion $(1 \%)$, infection $(1 \%)$ and stiffness with infection $(1 \%)$.

Table 12: Showing overall complication rate of patients in various studies.

\begin{tabular}{|ll|}
\hline Study & \% of complicated patients \\
\hline Moore $^{17}$ & $19 \%$ \\
\hline Lachiewicz $^{23}$ & $26 \%$ \\
\hline Our study & $19 \%$ \\
\hline
\end{tabular}

Wound infections remain a serious problem in the treatment of tibia plateau fractures, with infection rates ranging from $3 \%$ to $32 \%$. Barei et $\mathrm{al}^{24}$ et al. performed a study analyzing the complications after ORIF of tibial plateau fractures. In $8.4 \%$ of 83 patients, a deep wound infection developed that required an average of 3.3 additional procedures to clinical resolution. They state that with proper timing of the internal fixation and precise tissue handling, high-energy tibial plateau fractures can be safely treated. In our study two patients reported post-operative infection (Table 13). Both the patients were managed successfully conservatively by administration of intravenous antibiotics.
Table 13: Showing infection rate of patients in various studies.

\begin{tabular}{|ll|}
\hline Study & Infection rate \\
\hline Lin $\mathrm{S}^{25}$ & $7.8 \%$ \\
\hline Ballmer $^{26}$ & $0 \%$ \\
\hline Waddell & \\
\hline Our Study & $2 \%$ \\
\hline
\end{tabular}

In our study, none of the cases were reported to have complications such as non-unions, neurovascualar complications. In an earlier study by Schatzker, ${ }^{4}$ the most common complication was a peroneal nerve injury. In this study, there were no cases of perineal nerve injury.

One of the patients complained to prominent hardware. Implant removal was done as the fracture was healed by then, resulting in a satisfactory outcome following implant removal.

Functional outcome of the treatment also depends upon activity levels of the patients. In the study 22 out of 28 patients $(78 \%)$ in the high activity group achieved excellent results. The high activity group included farmers, laborers, and manual workers. While in the sedentary group only 8 out of 15 patients (53\%) had excellent outcomes. The sedentary group included housewives, patients with office jobs, and retired, unemployed patients. 
Table 14: Showing mean MRS at final follow-up in different Schatzker types.

\begin{tabular}{|lll|}
\hline Type & Persiani $^{29}$ & Our study \\
\hline I & $26.1 \%$ & $26.4 \%$ \\
\hline II & $24.3 \%$ & $27.25 \%$ \\
\hline III & $23.8 \%$ & $25.29 \%$ \\
\hline IV & $25 \%$ & $24.5 \%$ \\
\hline V & $22.6 \%$ & $24.6 \%$ \\
\hline VI & $25 \%$ & $23.75 \%$ \\
\hline
\end{tabular}

Table 15: Showing percentage of satisfactory results in various studies.

\begin{tabular}{|c|c|}
\hline Our study & $\%$ of satisfactory results \\
\hline Lachiewicz $^{24}$ & $93 \%$ \\
\hline Honkonen $^{14}$ & $86 \%$ \\
\hline Schatzker $^{4}$ & $86 \%$ \\
\hline Rademakers $^{19}$ & $84 \%$ \\
\hline Our Study & $84 \%$ \\
\hline
\end{tabular}

In this series, the initial types (Type I, II and III) had most favorable final functional outcomes (mean MRS 26.4, 27.25, 29 respectively) (Table 14). These results are similar to Stokel and Sa-dasivan $(1991)^{28}$ and Ebraheim et al. $^{22}$ Hence, we can conclude that as the fracture complexity increases, the rate of poor results also increases. Final functional outcome in our series was $84 \%$ had satisfactory results $(71 \%$ excellent, $13 \%$ good result). These results are comparable and on par with other documented standard studies (Table 15).

\section{CONCLUSION}

To meet the higher functional demands of the younger population and keeping in mind the fact that tibial plateau makes up one of the major weight bearing surfaces in the body, surgical treatment is warranted in most of the cases.

The aim of surgical treatment is rigid fixation of the bone with reconstruction of the articular surface and restoration of the depressed fragment, so that early range of motion and return to function can be provided.

There is no universal modality of surgical treatment. The choice of surgery depends upon the fracture morphology, functional demands of the patients and surgeon preference.

Although the surgical treatment of tibial plateau fractures is challenging, yet it yields in excellent anatomical reduction and rigid fracture fixation and enables the restoration of articular congruity and facilitation of early knee motion thus achieving optimal knee function.

Funding: No funding sources Conflict of interest: None declared

Ethical approval: Not required

\section{REFERENCES}

1. Leadbetter GW, Hand FM. Fractures of the tibial plateau. J Bone Joint Surg. 1940;22(3):559-68.

2. Barr JS. The treatment of fracture of the EXTERNAL tibial condyle: (Bumper fracture). J American Med Assoc. 1940;115(20):1683-7.

3. Albuquerque PR, Hara R, Prado J, Schiavo 1, Giordano V, Pecegueiro do Amaral N. Epidemiological study on tibial plateau fractures at a level I trauma centre. Acta Ortopedica Brasileira. 2013;21(2):109-15.

4. Schatzker J, McBroom R, Bruce D. The Tibial plateau fracture: the Toronto experience 1968-1975. Clin Orthopaed Related Res. 1979;138:94-104.

5. Marsh JL, Slongo TF, Agel J, Broderick JS, Creevey W, DeCoster TA et al. Fracture and dislocation classification compendium-2007: orthopaedic trauma association classification, database and outcomes committee. J Orthop Trauma. 2007;21(10):S1-133.

6. Sever JW. Fracture of tuberosities of Tibia, a report of three cases. Am J Orthop Surg. 1916;14:299-302.

7. Cotton FJ, Berg R. Fender fracture of the tibia at the knee. New England J Med. 1929;201(20):989-95.

8. Dobelie M. A new method of closed reduction of fracture of the lateral condyle of the tibia. American J Surg. 1941;53(3):460-2.

9. Maisel B, Cornell NW. Conservative treatment of fractures of the tibial condyles. Surgery. 1948;23(3):591.

10. Fyshe TG. Fractures of tibial condyles. Canadian Med Assoc J. 1952;67(2):103.

11. Savoie FH, Vander Griend RA, Ward EF, Hughes JL. Tibial plateau fractures. A review of operative treatment using AO technique. Orthoped. 1987;10(5):745-50.

12. Scotland T, Wardlaw D. The use of cast-bracing as treatment for fractures of the tibial plateau. J Bone Joint Surg Br. 1981;63:575-8.

13. Rasmussen PS. Tibial condylar fractures. J Bone Joint Surg. 1973;55(7):1331-50.

14. Honkonen SE. Indications for surgical treatment of tibial condyle fractures. Clin Orthop. 1994;302:199205.

15. Stevens DG, Beharry R, McKee MD, Waddell JP, Schemitsch EH. The long-term functional outcome of operatively treated tibial plateau fractures. J Orthopaed Trauma. 2001;15(5):312-20.

16. Myatt RW, Miles J, Matharu GJ, Cockshott S, Kendrew J. The Financial Cost of Managing Tibial Plateau Fractures at a Major Trauma Centre. Trauma. 2014;17(1):33-8.

17. Moore TM, Patzakis MJ, Harvey JP. Tibial plateau fractures: definition, demographics, treatment rationale, and long-term results of closed traction management or operative reduction. J Orthopaed Trauma. 1987;1(2):97-119.

18. Unnikrishnan J, Jacob PJ, Francis J. Functional outcome of tibial condyle fractures following open 
reduction and internal fixation with plate and screws. Kerala J Orthopaed. 2013;26(2):98-106.

19. Rademakers MV, Kerkhoffs GM, Sierevelt IN, Raaymakers EL, Marti RK. Operative treatment of 109 tibial plateau fractures: five-to 27-year followup results. J Orthop Trauma. 2007;21:5-10.

20. Manidakis N, Dosani A, Dimitriou R, Stengel D, Matthews S, Giannoudis P. Tibial plateau fractures: functional outcome and incidence of osteoarthritis in 125 cases. Int Orthop. 2010;34(4):565-70.

21. Dall'Oca C, Maluta T, Lavini F, Bondi M, Micheloni GM, Bartolozzi P. Tibial plateau fractures: compared outcomes between ARIF and ORIF. Strategies Trauma Limb Reconstr. 2012;7(3):163-75.

22. Ebraheim NA, Fady FS, Steven PH. Open reduction and internal fixation of 117 tibial plateau fractures. Orthopedics. 2004;27(12):1281-7.

23. Lachiewicz PF, Funik T. Factors influencing the results of Open reduction and Internal fixation of tibial plateau fractures. Clin Orthop. 1990;259:210.

24. Barei DP, Nork SE, Mills WJ, Henley MB, Benirschke SK. Complications associated with internal fixation of high-energy bicondylar tibial plateau fractures utilizing a two-incision technique. J Orthop Trauma. 2004;18(10):649-57.
25. Lin S, Mauffrey C, Hammerberg ME, Stahel PF, Hak DJ. Surgical site infection after open reduction and internal fixation of tibial plateau fractures. European J Orthopaed Surg Traumatol. 2014;24(5):797-803.

26. Ballmer FT, Hertel R, Hubert PN. Treatment of tibial plateau fractures with small fragment internal fixation: a preliminary report. J Orthop Trauma. 2000;14(7):467-74.

27. Waddell JP, Johnston DWC, Arvo N. Fractures of the tibial plateau: a review of ninety-five patients and comparison of treatment methods. J Trauma Acute Care Surg. 1981;21(5):376-81.

28. Stokel EA, Sadasivan KK. Tibial plateau fractures: standardized evaluation of operative results. Orthopedics. 1991;14(3):263-70.

29. Persiani P, Gurzì MD, Di Domenica M, Rosi S, Attala D, Villanet C. Risk analysis in tibial plateau fractures: association between severity, treatment and clinical outcome. Musculoskeletal Surg. 2013;97(2):131-6.

Cite this article as: Jain RK, Shukla R, Baxi M, Agrawal U, Yadav S. Evaluation of functional outcome of tibial plateau fractures managed by different surgical modalities. Int J Res Orthop 2016;2:5-12. 